\title{
Глобализация. Модернизация. Россия
}

Круглый стол

От редакции. Продолжая рассмотрение темы модернизации, предлагаем вниманию читателей материалы круглого стола, посвященного обсуждению соотношения между модернизацией и глобализацией, а также анализу влияния этих процессов на Россию. В работе круглого стола, состоявшегося в декабре 2002 г. на кафедре политического анализа факультета государственного управления МГУ, приняли участие сотрудники кафедры - зав.кафедрой, д.филос.н Г.А.Белов, д.пол.н., профессор А.И.Соловьев, к.филос.н., доцент Т.П.Лебедева, аспиранты Ю.С.Назарова и И.А.Рысева, а также декан факультета политологии МГИМО (У), д.филос.н. А.Ю.Мельвиль и зав.кафедрой социологии Высшей школы экономики, д.филос.н. Н.Е.Покровский.

А.И.Соловьев. Парадоксы глобализации уже давно стали предметом острых теоретических дискуссий. И это неудивительно, ибо неоднозначность разворачивающихся на наших глазах процессов неизбежно отражается на представлениях о них. По мере осмысления глобализации, еще только обретающей свои социальные и политические очертания, возникают все новые и новые ее интерпретации, некоторые из которых достаточно фундированы, а некоторые (особенно в рамках отечественной интеллектуальной традиции) - крайне поверхностны. Весьма характерно также редуцирование всего разнообразия мировых тенденций исключительно к глобализации или ее последствиям.

Сегодня нам предстоит обсудить многие аспекты глобализации и попытаться найти ответы на целый ряд встающих в связи с ней вопросов. Как соотносятся процессы глобализации и модернизации? Является ли глобализация линейным продолжением транснационализации или же речь идет о качественном повороте в эволюции человечества? Носит ли она стадиальный характер и в каких координатах оценивать ее нынешние последствия: чудовищный разрыв в развитии отдельных стран, политическую униполярность мира, появление новых социокультурных “берлинских стен” и т.д.? Какой пласт преобразований — технологический, экономический или социокультурный - сейчас доминирует, задает траектории развития на мировом и страновом уровне? Способны ли происходящие в настоящее время процессы действительно организовать мир в единое целое или же еще не одному поколению предстоит жить в условиях сегментации?

Говоря о глобализации, нельзя забывать о том, что ее сущностные параметры лишь частично проявляются в локальных политических пространствах. Это особенно важно учитывать, поскольку она представляет собой не только базовый тренд мировой политики, но и органический элемент внутригосударственных трансформаций. Страны, по-разному открытые глобальным процессам и по-разному использующие их возможности, различаются не просто по степени глобализации, но и по ее характеру.

Не будет преувеличением сказать, что нас в первую очередь интересует, как должны реагировать на складывающуюся ситуацию государства-системы, государства-цивилизации, подобные Китаю и, конечно, России. Воспринимая себя обществом, так или иначе вошедшим в Современность, должны ли мы видеть в себе “жертву” глобализации либо вполне достаточно осознавать, что мы по-своему встраиваемся в глобальные мировые порядки? Следует ли нам концентрировать усилия на развитии информационной, материальной, финансовой инфраструктуры или же целесообразно сосредоточиться на укреплении социокультурных и гуманистических технологий, облегчающих адаптацию наших сограждан к новым реалиям?

Методологически - да и практически - важно, чтобы теоретическая рефлексия не заслонила поиск конкретных маркеров глобализации, а также индикаторов обусловленных ею перемен, выразившихся, в частности, в трансформации политических институтов, структур, отношений. Это весьма принципиально, так как уже сейчас отчетливо прослеживается тенденция к вытеснению политики из сферы регулирования социальных процессов. На смену политическим рычагам приходят финансовые, которые вынуждают целые 
страны осуществлять те или иные преобразования, вводить технические и экономические инновации, иначе готовить свои кадры и даже формировать свои властные структуры. При этом интересно не только посмотреть, как преломляются названные процессы в различных странах, но и попытаться определить, какие параметры существующего поля политики содержат в себе прообразы недалекого будущего.

Как видите, вопросов немало, и думаю, что сегодняшняя дискуссия тоже обозначит немало острых проблем.

Н.Е.Покровский. Наше научное сообщество словно очнулось ото сна и обнаружило, что на дворе глобализация. И теперь всяк в силу своего разумения желает высказать суждение по поводу этого загадочного явления. Между тем в зарубежных социальных науках уже не менее 10-12 лет идет интенсивнейшая дискуссия о глобализации, породившая сотни книг и статей.

Эти наработки чаще всего остаются за пределами внимания российских участников глобализационных штудий. В трудах наших соотечественников преобладают чисто эмоциональные оценки нового состояния мира с позиций “взгляд и нечто” или же рассуждения о том, насколько происходящие плохо для России в принципе. Российский глобализационно/антиглобализационный дискурс носит преимущественно историософский, парасоциологический характер; он не только не опирается на взвешенный рационалистический анализ, лишенный априорной ценностной нагрузки, но, наоборот, апеллирует к “сердцу” и ориентируется на художественно-публицистические способы аргументации (образы и метафоры).

Однако объективная ситуация достаточно серьезна. Глобализация не просто стоит у ворот России, она в эти ворота уже вошла, не спросив на то разрешения. Анализ эмпирических данных показывает, что представление о том, будто Россия замедленными темпами адаптируется к общемировым изменениям, не имеют под собой оснований. Напротив, в связи с ослабленностью социальной структуры российского общества в нем активно развиваются важнейшие глобалистические тенденции. Более того, российское общество в каком-то смысле сильнее подвержено влиянию этих тенденций, нежели стабильные западные общества, и выступает в качестве своеобразного “полигона”, на котором испытываются те феномены, которые лишь в будущем полностью проявят себя в глобальном формате.

В рамках существующих на сегодняшний день теорий выделяются следующие ключевые тенденции, возникающие при вступлении в эпоху глобализации: (1) всеохватность и комплексность изменений, трансформация всех параметров социальных структур; (2) доминирование глобальных ценностей и ориентиров над локальными; (3) гибридизация культуры; (4) ослабление национально-государственного фактора, превращение гражданского общества в единственную форму упорядочения глобального социума; (5) раскрепощение “глубинных” (примордиальных) феноменов; (6) переход от “современного” к “постсовременному” типу рациональности с его акцентом на мозаичность и внутреннюю несвязанность восприятия и конструирования социальной реальности. Прежде чем приступать к развернутому обсуждению этих тенденций, хотелось бы отметить, что американизация, по сути, представляет собой конкретизацию глобализации с включением в нее элементов американской национальной культуры. Особенности американизации в области культуры заключаются в иррационализации рациональных матриц, в упоре на количественные характеристики (коммерциализация) и готовность к употреблению (оперантность), в поддержании определенного уровня качества, а также в виртуализации культурных образов. При этом происходит создание как бы новой рациональной системы, которая выступает антиподом старой, связанной с традиционной культурой.

Вернемся, однако, к перечисленным выше тенденциям.

1. Всеохватность и комплексность изменений. Теоретики глобализации делают акцент не на конкретных изменениях в отдельных областях, а на переплетении и взаимополагании этих изменений. Это подразумевает концентрацию внимания на пространственно-географических параметрах инноваций, их глобальной релевантности. Процесс трансформации проникает во все микроструктуры общества (семья, малые группы, повседневность), делая проницаемыми прежде герметичные социальные образования. Быть замкнутым на себе и отгражденным от внешнего мира сегодня означает перечеркнуть свое будущее. Любые формы социальной динамики связаны прежде всего с открытостью систем, формирующих сетевые структуры общения, поддержки и социального контроля. Углубление данных процессов влечет за собой и изменение восприятия социального времени. Последнее распадается на серию отрезков, каждому из которых соответствует особый, краткосрочный жизненный “проект”. После окончания очередного проекта возникает 
новый, часто радикально меняющий траекторию развития. Подобная “экспериментальность” социальных практик пронизывает все уровни социальной структуры. Даже такие традиционные институты, как семья, превращаются для вовлеченных сторон в эксперимент. Все начинает носить преходящий характер и требует от субъектов постоянного “вписывания” в эту быстротечность. Изменчивость и “пластичность” становятся главными позитивными ценностями.

2. Доминирование глобального над локальным. Важной особенностью глобализации является то, что она проникает в самые глубины социальных структур, превращая их в носителей новых смыслов. Глобальные реалии кардинально модифицируют даже наиболее консервативные и устойчивые структуры социального сознания и поведения. Процесс “отказа” от “старого” идет быстро, решительно, зримо. Причем всякое “новое” считается заведомо лучшим, поскольку оно “глобальное”. “Глобальное” приобретает статус высшей нормативной ценности. Локальным социальным институтам отныне не нужно проходить все ступени вертикальной иерархии, дабы выйти на общемировой уровень. Семья, малые группы, местные организации, движения и институты глобализируются прямым и непосредственным образом, демонстрируя новые формы участия в глобальных процессах. Более того, локальные структуры могут сохранить себя только в том случае, если между ними складываются сетевые связи, способные к глобализации на своем уровне. Значение вертикальных иерархий резко снижается. Информация, финансирование, помощь циркулируют по горизонтальным сетям, а не спускаются “сверху”. Различные уровни дистанцируются друг от друга и начинают вести самостоятельную, самодостаточную жизнь. Развивающуюся тенденцию наглядно иллюстрирует растущее разочарование электората в макрополитике. Вместе с тем углубление взаимного равнодушия между вертикальными уровнями наблюдается повсеместно.

3. Гибридизация культуры. Глобализация радикально меняет наши представления о культуре как о чем-то наследуемом либо спускаемом “сверху” и “распространяемом”. В новых условиях культура становится результирующей бурного процесса “политизированного оспаривания” (politicized contestation), что ведет к появлению разнообразных глобальных и локальных “социокультурных гибридов”, часто состоящих из несовместимых частей, крайне нестабильных и противоречащих традиционному контексту.

4. Ослабление национально-государственного фактора. Глобализационные тенденции подрывают значение национализма во всех его проявлениях, будь то нации-государства, национальные социокультурные традиции или соответствующие типы сознания. Национально-государственный фактор несомненно сохраняется (в т.ч. в виде отдельных государств, правительств и т.д.), но перестает быть определяющим. Общества начинают образовывать свои конгломерации, имеющие сквозные горизонтальные структуры.

5. Раскрепощение примордиальных феноменов. Процесс интернализации ценностей и ценностных ориентаций приводит к тому, что регулятивно-нормативная функция общества существенно трансформируется и прежде подавлявшиеся гражданским обществом и не социализировавшиеся “примордиальные” феномены, близкие по природе к фрейдовскому Id и мидовскому I, занимают все более важное место в глобальных процессах и институтах. Мозаичный набор социальных “типов” и моделей, отсутствие единых принципов рационализации, свобода обращения с примордиальными феноменами неотъемлемые составляющие глобалистско-постмодернистской картины мира.

6. Переход к “постсовременному” типу рациональности. Представляя собой особую нормативно-теоретическую парадигму, глобализация перечеркивает и прежнюю концепцию рациональности, сложившуюся в рамках “современного общества”. Новая модель рациональности, предполагающая прежде всего свободу многообразия, находит свое воплощение в “теории мультикультуризма”, в основу которой положен принцип мозаичности культурных “карт” региональных и профессиональных групп.

Многие, если не все обозначенные выше позиции, вызывают резкое неприятие со стороны традиционных организаций и субъектов, плохо приспособленных к новым условиям, подразумевающим внутреннюю динамику, готовность к изменениям, открытую соревновательность, а значит - и повышенную ответственность, которая связана с высокой степенью риска. Более того, нужно отдавать себе отчет в том, что глобализированное общество отнюдь не гарантирует своим членам бесконфликтное существование. Глобализация - жестокий процесс, который лишь переводит прежние конфликты в новое измерение.

Однако проблема в том, что альтернативы глобализации практически нет. Пасьянс важнейших факторов мирового развития разложился таким образом, что новый тип рациональности диктует свои правила вне 
зависимости от субъективного желания тех или иных акторов. Последние должны либо произвести внутреннюю мобилизацию и переструктурацию своих систем и включить их в процесс глобализации максимально эффективным способом, либо сойти с дистанции и вверить свою судьбу внешним силам, которые рано или поздно осуществят эту переструктурацию по своему разумению. Перед подобным выбором стоят сегодня не только крупные общественные структуры, но и каждый отдельный человек. И это необходимо знать.
А.Ю.Мельвиль. Вот уже почти десятилетие и в зарубежном, и российском политическом (и околополитическом) дискурсе господствует представление о том, что глобализация и демократизация - не просто доминантные, но и взаимодополняющие и взаимоподкрепляющие тенденции развития современного мира. Более того, данный тезис обычно преподносится как нечто само собой разумеющееся и потому не нуждающееся в сколько-нибудь развернутой теоретической аргументации. В лучшем случае можно натолкнуться на некое подобие силлогизма (очень напоминающее известную “гипотезу Липсета” о зависимости демократии от уровня экономического развития и достатка): глобализация порождает качественно новый экономический рост, способствующий появлению или расширению образованного среднего класса, от которого, в свою очередь, исходит новый мощный импульс в пользу демократических реформ. Несколько огрубляя, можно сказать, что представление о взаимообусловленности глобализации и демократизации чаще всего возникает как бы а priori, на уровне “души и сердца”.

\begin{abstract}
Между тем опыт последнего десятилетия заставляет отнестись к такой “связке”, да и к ее “звеньям” глобализации и демократизации - по крайней мере cum grano salis. Думается, что оба эти феномена и отношения между ними гораздо сложнее и неоднозначнее, чем принято считать.
\end{abstract}

С одной стороны, вроде бы действительно имеются признаки того, что в современном глобализирующемся мире постепенно расширяется пространство свободы и демократии, но с другой - есть немало фактов, свидетельствующих об обратном. Так, согласно докладу Freedom House, в 2002 г. в мире стало на четыре “свободных” страны больше, чем в 2000 г. Однако при этом налицо симптомы не только стабилизации “частично свободных”, или “переходных”, стран в их “гибридном” состоянии, но и превращения формально существующих там демократических институтов и практик в фасад, за которым скрываются новые разновидности авторитарного правления и воспроизводства власти, что фактически указывает на затухание “третьей волны демократизации”.

Очевидно, что демократические тенденции реально сказываются на функционировании таких международных институтов, как Европейский Союз и Организация американских государств, условием вступления в которые выступает соответствие демократическим критериям. В то же время в мире действует целый ряд организаций, безразличных к внутреннему устройству своих членов, — например, Ассоциация государств Юго-Восточной Азии (АСЕАН) или Азиатско-Тихоокеанское экономическое сотрудничество (АТЭС). Новые информационные и коммуникационные технологии все сильнее связывают между собой страны и регионы (“эффект CNN”), но ими пользуются и авторитарные режимы, а также международные террористические силы (та же Аль-Каеда). И если в одних случаях экономический рост в условиях глобализации и в самом деле стимулирует демократические реформы (как это было в Южной Корее или на Тайване), то в других он лишь укрепляет легитимность авторитарных режимов (как в Сингапуре или в Саудовской Аравии). Иными словами, причинная зависимость между глобализацией и демократизацией, как минимум, не линейна.

Да и сама глобализация, если внимательно присмотреться, образует далеко не однозначный контекст для демократизации. “Сращиванию” современного мира, становлению транснациональных экономических, политических и культурных пространств сегодня противостоят мощные центробежные тенденции. Создавая благоприятные условия для кооперации и сотрудничества, “сужающийся” под влиянием глобализации мир одновременно становится более “проницаемым” для конфликтов и насилия. И хотя глобализация и демократизация, казалось бы, только подкрепляют кантовскую теорему “демократического мира” (демократические государства не воюют друг с другом), сам процесс транзита, перехода и трансформации внутриполитических режимов может выступать фактором дестабилизации международного порядка.

Дестабилизация, конфликты, социально-экономическая поляризация - такие же последствия глобализации, как и единые финансовые рынки, транснациональные потоки капитала и информации, конвергенция ценностей и стилей жизни. Глобализация не только “сжимает” наш мир, но и “раскалывает” его, причем во многих отношениях — экономическом, социальном, технологическом и т.д. Образ “однополюсной 
цивилизации” (В.Л.Иноземцев) не просто фиксирует гигантский отрыв стран “золотого миллиарда” от остального человечества, он подразумевает и наличие зоны нищеты и упадка. Но это означает, что одним из теоретически возможных сценариев дальнейшего развития является утверждение отнюдь не демократического, а имплицитно совершенно авторитарного глобального миропорядка.

Глобализация ведет к расслоению и увеличению степеней неравенства на планете, закрепляет за безнадежно отставшей “мировой периферией” роль ресурсного придатка постиндустриального авангарда, сводит на нет перспективы “догоняющего развития”. Под вопросом, тем самым, оказывается и упомянутый выше силлогизм, опирающийся на “гипотезу Липсета”: если глобальный рынок углубляет раскол мира, то способствует ли он или, наоборот, препятствует демократизации?

Раскол современного мира под воздействием глобализации приобретает не только социально-экономический, но и политический и (вопреки нередко звучащему тезису о “всеобщей макдоналдизации”) культурно-цивилизационный характер. Уже один только нынешний мощный всплеск исламского фундаментализма полностью разрушает идиллический образ симбиоза глобализации и демократизации. (В качестве иллюстрации: “поздний” Ф.Фукуяма с его паникой по поводу волны “исламо-фашизма” звучит почти как “ранний” С.Хантингтон с его “конфликтом цивилизаций”).

Рискну предположить, что глобализация перестраивает само проблемное поле, в котором дается определение демократии. В первую очередь речь идет об изменении “масштабов” демократии и “единицы” демократического устройства. Подобно тому как демократия античного полиса не подходит для национального государства, институты и практики современной демократии, возникшие в рамках национальных государств, плохо приспособлены к условиям глобализирующегося мира.

Общим местом в дискуссиях о глобализации стало положение об “эрозии” национального государства как центральной политической единицы властных решений. Действительно, глобализация как бы надстраивает над современным национальным государством “транснациональные своды”, но при этом ее неизменная спутница — локализация/фрагментация - множит центры эффективных властных решений на уровнях “ниже” национального, открывая новые субнациональные пространства. В связи с этим, собственно, и возникает вопрос о характере и содержании демократии “выше” и “ниже” уровня национального государства.

Применительно к сфере международных отношений и мировой политики названный вопрос может быть переформулирован следующим образом: нужны ли (а главное - возможны ли) новые демократические институты и практики для управления глобальными процессами? Согласно одной (традиционной) точке зрения, идеалом мироустройства является мир демократических государств, по определению сохраняющих атрибуты национального суверенитета. Демократизация в данном случае понимается преимущественно как “внутренний” процесс, развивающийся в рамках национального государства. В соответствии с другой точкой зрения, желанной целью выступает “глобальная”, “космополитическая демократия” (Д.Хелд) формирование мирового демократического сообщества, в котором демократические институты и практики “поднимутся” на транснациональный уровень и одновременно “опустятся” (минуя национальное государство) на уровень субнациональный, создавая, тем самым, “горизонтально-вертикальную” сеть демократических взаимодействий. При такой трактовке демократизация приобретает черты процесса, протекающего прежде всего на глобальном уровне, но проникающего и на уровень “ниже” национального государства.

За видимой утопичностью второй точки зрения стоят, однако, вполне реальные тенденции в развитии международных отношений, в частности, расширение числа акторов мировой политики за счет включения в их состав как наднациональных (ТНК, международные направительственные организации и т.д.), так и субнациональных (отдельные регионы стран, общественные и иные движения и даже отдельные лица) игроков. Аналогичным образом можно интерпретировать и некоторые новые явления в сфере международных политических взаимодействий, размывающие традиционные представления о национальном суверенитете и границах между внутренней и внешней политикой (например, “гуманитарные интервенции”, введение международных критериев соблюдения прав человека, появление международных трибуналов и др.). В этом смысле действительно есть основания говорить о том, что процессы, ассоциирующиеся с “внутренней” демократизацией, начинают выходить на транснациональный уровень.

Тем не менее и здесь картина далеко не однозначна. Глобализация и порождаемые ею новые конфликты и 
проблемы подспудно размывают казалось бы незыблемые оценочные критерии отнесения к демократиям и “недемократиям”. Так, после событий 11 сентября 2001 г. западному миру, возможно, придется заново переосмыслить вопрос о том, какие внутри- и внешнеполитические действия отвечают демократическим стандартам, а какие нет. Помимо прочего, Западу предстоит определиться в отношении неожиданно остро вставшей дилеммы личной свободы (в т.ч. в финансовой области) и общественной - национальной и международной - безопасности. Как далеко можно продвинуться в данном направлении, оставаясь в традиционном демократическом поле? Не приведет ли такое движение к отказу от самой идеи либеральной демократии с ее упором на примат индивидуалистического начала, индивидуальных прав и свобод?

Новые мировые угрозы (в первую очередь, международный терроризм) вносят коррективы и в критерии выбора партнеров на международной арене. Уже сегодня внутренне устойчивые недемократические страны, прежде всего в политически нестабильных и взрывоопасных регионах, зачастую воспринимаются как более привлекательные союзники, нежели “переходные”, но слабые режимы (весьма показательна в этом плане позиция американской внешней политики по отношению к Пакистану, но подобными соображениями руководствуется и Россия). Где уж тут до пуризма кантовского “демократического мира”, особенно если и сам искатель союзнических отношений еще не дотягивает даже до минимальных демократических стандартов.

Но у рассматриваемой проблемы имеется и еще один аспект. Демократизация, еще совсем недавно представлявшаяся нам глобальной по охвату и универсальной по влиянию “третьей волной”, по-видимому, сама нуждается сегодня в критическом переосмыслении. Я уже упоминал о том, что за фасадом формально демократических порядков нередко скрываются новые типы авторитаризма. Похоже, что вместо ожидавшегося неуклонного расширения пространства либеральных демократий, в современном мире происходит умножение демократий “дутых” (Л.Даймонд) — причем не только всевозможных гибридных политических режимов, в разных пропорциях и в разном качестве сочетающих демократические и авторитарные практики, но и откровенных псевдодемократий, лишь имитирующих некоторые ее формальные институты (например, выборы или многопартийность).

Быть может, еще преждевременно говорить (как это делают отдельные комментаторы) о “глобальной недемократической волне”. Вместе с тем при анализе траекторий политических трансформаций в современном мире методологически важно признать реальность возникновения новых разновидностей “недемократий” (т.е. полностью консолидированных версий авторитаризма), перестав описывать их как “недодемократии”, находящиеся в состоянии транзита. Конечно, по отношению к идеальным типологиям все существующие политические режимы — в той или иной степени смешанные, а демократия сама процесс эволюции, трансформации и развития. И все же компаративистам необходимо найти и обосновать критерии классификации новых политических режимов и режимных изменений, происходящих буквально на наших глазах — в т.ч. и под влиянием глобализационных сил и тенденций.

Таким образом, несмотря на пересечение соответствующих политических и проблемных областей, связи и соотношения между глобализацией и демократизацией многомерны и неоднозначны. Осмысляя данную ситуацию в категориях традиционной оппозиции либерально-индивидуалистического (“буржуа”) и мажоритарно-демократического (“гражданин”) начал в либеральной демократии, можно предположить, что тенденции глобализации более или менее созвучны ее “буржуазному” началу, однако ставят много проблем в отношении начала “гражданственного”. В самом деле, сегодня никто не в состоянии сказать, с помощью каких конкретно институтов и практик можно будет осуществлять демократическое управление единым мировым сообществом в 6 млрд. человек, как повлияет на это сообщество эрозия национальных государств, как, наконец, будут меняться сами критерии демократии под воздействием “внутренних” и “внешних” для нее процессов.

Искать ответы на эти и многие другие вопросы предстоит и политологам, и международникам, и регионоведам, и компаративистам, словом, всем, кто занимается проблемами современного политического развития и мировой политики.

А.И.Соловьев. Мы уже постепенно свыкаемся с тем, что политические изменения в различных странах мира в той или иной степени являются составными частями мегаполитического процесса, и наоборот. Осознание такой транснационализации политики проблематизирует именно те формы соприкосновения глобальных и локальных практик, которые, с одной стороны, влияют на мировую систему (или даже меняют существующую там конфигурацию сил), а с другой - задают векторы развития на страновом, 
Понятно, что выстраивание нового мира носит не столько незавершенный, сколько открытый характер. Очевидно и то, что этот процесс сопряжен с усилением неравновесности, а по сути дела — и с хаотизацией политических порядков, с трудом поддающихся какой-либо целостной оценке. Учитывая несоизмеримость — и даже несопоставимость - факторов мировой политики (силовых, экономических, нормативных и прочих), важно выявить некие основополагающие зависимости, действующие в данной сфере, постараться обнаружить поворотные точки во взаимоотношениях локального и глобального.

Около двух десятилетий назад базовой считалась связь человека и природы, а главной проблемой — вопрос о том, как совместить экономический рост с уменьшением антропогенной нагрузки на природу. В настоящее время фокус внимания смещается в область взаимодействия различных социально-экономических и политических тенденций, определяющих параметры отношений между человеком и природой, государством и обществом, властью и индивидом. Предельно огрубляя ситуацию, можно сказать, что “первую скрипку” начинают играть факторы высшего уровня, направляющие и даже в какой-то степени программирующие движение отдельных политических локалитетов, ибо именно они формируют новый тип отношений человека с природой, способствуя при этом и росту энтропии старого порядка распределения власти в мировом пространстве. Появление так наз. “штабной экономики” и электронного бизнеса, а также сопутствующих им политических структур, сетевая организация межрегиональных связей и другие аналогичные следствия глобализации довольно ясно очерчивают перспективные векторы эволюции стран и территорий. В этих условиях любые разговоры о “третьем” или “особом” пути есть не более чем консервативная утопия, лишь тормозящая развитие общества.

На данный момент лидирующую роль в становлении связей транснационального типа играют экономические факторы. Собственно политика пока выполняет в этом процессе скорее вторичные функции, приспосабливая механизмы представительства интересов к взаимоотношениям ТНК, обеспечивая складывание новой международной элиты и т.д. Вместе с тем политический компонент остается ведущим с точки зрения выбора модели национального развития. Формы включения в мир глобальной экономики, выстраивание соответствующих структур, обретение адекватных коммерческих, технических и информационных ресурсов - все это, строго говоря, является вопросом политического воления. Именно от политического воления зависит отношение к общесоциальным интересам, статусу национальной государственности, проблемам безопасности, только оно может обеспечить переориентацию отраслей на производство наукоемких и информационных технологий, изменение системы подготовки и переподготовки кадров и осуществление других, нередко весьма затратных и болезненных мер, без которых общество обречено оставаться на периферии и полупериферии глобализации.

Хочу подчеркнуть, что политическое воление отнюдь не равнозначно произвольности выбора, но предполагает достижение согласия ведущих игроков на поле власти относительно сознательного разворота в сторону глобального проекта. Как бы то ни было, включиться в процесс глобализации “самотеком”, без политического решения национального масштаба в принципе невозможно - во многом потому, что помимо глобализационных тенденций в современном мире действуют и тенденции к модернизации и традиционализации. Данные мировые тренды тоже имеют свою социальную и политическую почву. Более того, для ряда стран модернизация открывает весьма неплохие - по сравнению с имеющимися возможности развития. В некоторых обстоятельствах (особенно тогда, когда вследствие просчетов правящей элиты страна все больше утрачивает конкурентоспособность на международной арене) привлекательной стратегией может оказаться и архаизация.

Учитывая политический потенциал каждой из названных тенденций, есть основания говорить о незавершенности их исторического спора. Мало того, этот спор сейчас обострился в связи с появлением на поле мировой политики новых акторов, в частности международного терроризма, достигшего принципиально иного уровня “оппонирования” цивилизованным странам. Нельзя исключить, хотя бы чисто теоретически, что в ситуации углубления экологических, технократических и прочих рисков политическое давление радикального фундаментализма на глобализацию и сложившийся миропорядок может привести не только к торможению базовых трендов развития, но и к качественному изменению характера межгосударственного общения. Во всяком случае “общество страха” (У.Бек), способное трансформировать приоритеты как мирового, так и локального развития, — отнюдь не литературный вымысел.

Но даже отвлекшись от этой, пока еще гипотетической, перспективы, не следует забывать, что в мировом 
сообществе, наряду с тенденцией к делокализации экономики, политики и культуры, сложилась и тенденция к релокализации. Появление у локалитетов новых экономических и политических ресурсов позволяет им не просто выживать в условиях интенсификации транснациональных отношений, но и налаживать экономические, политические и иные контакты с различными контрагентами. Не случайно от локальных образований так часто исходит инициатива создания всевозможных горизонтальных, сетевых структур.

Приобретение локалитетами ресурсов для относительно самодостаточного существования по сути означает наступление стадии их политического раскрепощения. Дополнительные стимулы к активному социальному проектированию, к расцвету политической инженерии создают телеологические искушения местных элит. (Попутно отмечу, что именно вследствие этого обстоятельства в современном мире и обостряется конфликт между логикой линейной эволюции и, условно говоря, логикой “ветвления”, закрепляющей приоритет не универсальных, а национально-специфических целей развития отдельных государств, территорий, сообществ.)

Конечно, тенденция к самодостаточности нередко вступает в противоречие с культурными основаниями жизнедеятельности локальных обществ, обладающих той или иной степенью восприимчивости к целями и ценностями транснационализма. Культурные клетки многих политических организмов срастаются с ценностями глобализации, но так происходит не всегда. По этой причине одни государства “молчаливо соглашаются” на экспансию глобализации, а другие нет.

В любом случае в переходных обществах рациональность никогда не доминирует полностью, а сопротивление архаики, которую невозможно органически встроить в постмодернистские проекты, порождает как инерцию и снижение темпов развития, так и риск выдвижения на первый план традиционалистской перспективы.

Поэтому вопрос политического выбора всегда остается эмпирическим, и его решение во многом диктуется партикулярными ценностями, действующими на той или иной территории. Если исходные молекулы политической культуры страны и культуры глобализации (или так наз. “новой политической культуры”, прокладывающей путь к постдемократизации общества) принципиально различны, то даже при создании отдельных политических институтов и отношений нового типа выбор в пользу глобализации состояться не может. Иначе говоря, “мыслить глобально” (Т.Вирт) можно в любых условиях и в любых странах, а вот “локально” действовать в этом духе получается далеко не у всех. И если в сегментированных политико-культурных пространствах еще могут возникать эпизодические контакты с ценностями “нового мира” и, как следствие, складываться определенные очаги глобализации, то культурно гомогенные традиционалистские общества вообще не имеют реальных шансов на включение в процессы глобализации.

О важности политического фактора свидетельствует и еще один существенный аспект становления нового мироустройства. Дело в том, что глобализация - довольно жесткий процесс, несущий с собой не только новую дифференциацию и новые экономические проблемы (в т.ч. новую бедность), но и углубление и так катастрофического неравенства стран и народов. Выстраивание нового типа отношений между центром и периферией способно повлечь за собой не просто долгосрочное отставание, а чуть ли не окончательное выпадение каких-то стран и народов из складывающегося миропорядка.

Фактическое превращение “ворот нового мира” в “служебный вход” для избранных вызывает резкое недовольство “отстающих от прогресса” государств, требующих смягчения последствий глобализации. Все громче звучат и предостережения интеллектуалов, указывающих на то, что переход к “однополярному миру” и доминирование стран “золотого миллиарда” чреваты “разрушением” мировой цивилизации. Для такого рода позиции, безусловно, имеются определенные социальные основания. Однако она невольно вызывает в памяти критику капитализма полутора-двухсотлетней давности, в частности, стенания по поводу торговых кризисов, якобы предвещающих мировую катастрофу. На самом деле идет естественный, хотя и болезненный, процесс образования нового типа центр-периферийных связей, где наиболее эффективные структуры имеют объективное превосходство. И мне кажется вполне справедливым, что лидеры глобализации извлекают из своего положения дополнительную прибыль.

Я думаю, что до тех пор, пока глобальный мир не станет системообразующим фактором нового мироустройства, глобализм вправе и дальше практиковать ультралиберализм и жесткий режим конкуренции. Реализация требований отстающих о смягчении их обязательства перед развитыми государствами, о более оптимальном распределении ресурсов и расширении гуманитарной помощи Запада 
неизбежно замедлит установление нового порядка, искусственно законсервирует нынешний хаос, активизирует радикальные формы политического протеста. А этот полу- (или четверть-) глобализм куда опаснее глобально выстроенного мира.

Политические факторы и ресурсы мира должны не тормозить, а стимулировать глобализацию, тем более что временное смягчение ситуации не снимет ответственности самих стран за выбор пути развития. Другими словами, если кто-то не успевает на поезд глобализации, он не должен минировать вокзал или валить на рельсы бревна - ибо страдать от этого придется пассажирам, т.е. гражданам наименее обеспеченных ресурсами стран. Политическая позиция — это не только понимание своих возможностей в мировом пространстве, но разумное обживание собственной ниши в мировой политике. Не следует забывать, что от политического выбора зависит и решение вопроса о том, помогать ли процессам глобализации либо создавать для них препятствия.

Очевидно, что России приходится решать те же универсальные задачи, что и другим странам, одновременно включенным в поле действия всех трех мировых трендов. Вместе с тем благодаря своей уникальной социокультурной “оснастке” наше общество обладает весьма специфической матрицей развития, предопределяющей характер встраивания его в новые порядки и степень влияния на ситуацию в мировой политике. Несмотря на намерения руководства решать “амбициозные задачи”, именно эта матрица и задает реальные параметры отечественной глокализации.

На мой взгляд, базовые флуктуации российского развития обуславливаются сегодня структурами и отношениями, действующими в рамках Модерна и отчасти традиционализма. Именно по этой причине сложившиеся у нас механизмы адаптации к постсовременным реалиям нередко сопротивляются инновациям в духе глобализации. Более того, нынешняя форма сопряжения двух доминирующих трендов, а также тот факт, что истоки происходящих в политическом пространстве страны процессов кроются скорее не в целенаправленном курсе правительства, предполагающем относительно сбалансированные акции правящей элиты, а в спонтанных и противоречивых политических проектах различных политических акторов, позволяют квалифицировать нашу модель национального развития как неомодернизацию.

Неомодернизация представляет собой сочетание конфликтующих между собой проективных практик, де-факто остающихся в историческом поле Модерна, но при этом резко усиливающих внутреннюю вариативность развития. В результате пороговые значения трансформаций становятся крайне размытыми, и общество обретает возможность встраиваться в совершенно разные по своей направленности процессы. В России такое неравновесное состояние уже обретает определенные черты институциональной устойчивости. Не случайно и сам процесс изменений, и его промежуточные итоги у нас настолько противоречивы, что некоторые видят в них признаки сближения с Западом и перехода от “делегативной” демократии к либеральной, а другие (в частности, Г.Явлинский) - симптомы “демодернизации”.

В экономическом отношении Россия в 10-12 раз отстает от Гонконга, Тайваня и других “азиатских тигров” капитализма, не говоря уже о Западной Европе и США. На фоне роста коррупции, приватизации и концентрации власти, обострения конфликтов довольно слабо выражены тенденции, сближающие нас с передовой частью мира (углубление межкультурного общения, развитие информационно-коммуникативных практик). Стремясь к интеграции с Западом, наша страна утрачивает ведущие позиции даже на пространстве СНГ, так и не сумев выступить лидером транснационализации в этой части мирового пространства.

И все же уровень политической культуры (несмотря на все ее интегральные колебания) и экономические показатели России сейчас достаточны для вполне направленных контактов с глобализирующимся миром. При том что экономика, система подготовки кадров и некоторые другие базовые структуры у нас порой не дотягивают даже до стандартов индустриальных обществ, сферы культуры, науки и искусства (в лице их видных представителей) уже включились в глобальные интеракции, прокладывая тем самым мостик между локальными и новыми мировыми порядками.

Но перспективы нашей страны определяются не столько успехами в каких-то отдельных, пусть и важных, областях, сколько эффективностью механизмов политических инноваций. Неомодернизация крайне диверсифицирует источники изменений в российском обществе, однако в рамках сложившегося на данный момент соотношения сил фактическим лидером в сфере политических инноваций - в т.ч. и в определении внешнеполитических стратегий — являются корпоративные структуры крупного капитала. В известном смысле правительство лишь подлаживается под их цели и ресурсные возможности. В этих условиях 
космополитизм корпоративных структур становится главным орудием включения страны в новые мировые порядки. И хотя сырьевой характер отечественных корпораций не позволяет им претендовать на ведущее место в глобализированной экономике, даже сохранив свои позиции на полупериферии, они дадут обществу шанс закрепиться в экономической системе нового мира.

Существует и еще одна нить, связывающая Россию с глобализирующимся миром. Как ни парадоксально, но в нашей стране (возможно, из-за аморфности ее экономических и политических структур) раньше, чем где бы то ни было, стала складываться медиакратия — постдемократическая модель управления массовым обществом, при которой политические и культурные формы влияния на власть по сути неразличимы. Правда, памятуя о специфике нашего государства, нельзя исключить, что опережающие темпы в выстраивании базовых элементов политической системы будущего приведут к неблагоприятным для России последствиям. Не защищенная демократическими традициями, профессионализмом элит и иными политическими механизмами, способными нивелировать негативные эффекты новых взаимоотношений между властью и обществом, Россия неизбежно столкнется с издержками медиакратических порядков. В результате потенциал медиакратии может оказаться направлен на усиление авторитарного характера ключевых структур и механизмов политической власти.

Принимая во внимание высказанные выше соображения, можно утверждать, что на данном этапе реальное продвижение России по пути интеграции в глобальный мир связано не с реализацией неких амбициозных проектов, а с осуществлением таких элементарных шагов, как вхождение в международные торговые и экономические организации и просто налаживание хороших двусторонних отношений с лидерами западных государств. Конечно, подобные акции не обеспечат нашей стране “билета” в мировое сообщество, но они позволят ей максимально воспользоваться политической благотворительностью “сильных мира сего” и выиграть время для перестройки своего технического потенциала, развития наукоемких отраслей и информационной инфраструктуры. Это даст нам возможность хотя бы “частями” вползти в новый мир и тем самым получить шанс на достойное будущее.

Г.А.Белов. Процессы глобализации и модернизации имеют много точек пересечения и порождают немало сходных проблем. Это объясняется тем, что глобализация, как и модернизация, предполагает обновление социумов, а с ними — и всего мира. Однако последствия обновлений всегда неоднозначны, неоднозначна и реакция на них. Будучи для одних источником оптимизма и надежд на улучшение жизни, у других они вызывают фрустрацию и отторжение. И это вполне понятно - ведь для многих людей обновление оборачивается не только нарушением привычных условий существования, но и маргинализацией. Сказанное полностью справедливо по отношению к глобализации, углубление которой неизбежно будет сопровождаться ростом протестного потенциала и социальной напряженности.

Противоречивые последствия глобализации непосредственно отражаются и на государстве. Под влиянием развивающихся в последние годы процессов государство оказалось в тяжелом (и нарастающем) системном кризисе. В чем же он выражается?

Похоже, что с глобализацией меняется само место государства во внутринациональных и мировых процессах, что связано прежде всего с увеличением числа экономических, социальных и политических акторов. Наряду с партиями и ассоциациями с государством сейчас взаимодействуют экономические корпорации и масс-медиа, элиты малых народов, различного рода правозащитные и экологические организации и т.д. Растет число заявок новых акторов на мировую активность. Усиление влияния неправительственных организаций, в первую очередь транснациональных корпораций, отчетливо обнаруживает неадекватность государствоцентричной модели мировой политики.

Уникальность новых вызовов государству состоит в их интенсивности и многообразии. В итоге государство не только утрачивает свои позиции на международной арене, но и перестает быть полновластным хозяином на собственной территории. Суверенитет государства “съеживается”, приобретает ритуальные черты. Традиционно широкое поле реальных и потенциальных государственных решений сокращается, что особенно заметно в странах с устойчивыми и давними этатистскими устоями. На фоне ослабевающей способности государства контролировать свою территорию растет разочарование граждан, поднимается новая волна национализма. Все это усиливает угрозу дезинтеграции государств, что негативным образом сказывается на политической жизни в целом.

Государственная территория — это минимальное геополитическое пространство государства, зона наиболее 
важных национальных интересов. В период после второй мировой войны нерушимость границ был объявлена основой международных отношений. Однако ирония в том, что превратившись, казалось бы, в незыблемую международную норму, принцип территориальной целостности стал разлагаться изнутри. Всеобщее признание данного принципа на государственном уровне не препятствует его повсеместному нарушению нетрадиционным, “глобалистским” способом. Мало того, прозрачность и размытость границ нередко устраивает сами государства, которые заинтересованы в размещении на своих землях иностранных инвестиций. Политический облик государственной территории теперь определяется уже не только внутриполитическими факторами, такими как политическая организованность социума, степень его этнической гомогенности и гражданской интегрированности, но и иными показателями. Выступая в качестве поля активности не только национальных, но и транснациональных акторов, а значит — и зоны рубежной коммуникативности, государственные территории все чаще оказываются смешанными геополитическими пространствами, где присутствуют элементы как тотальности, так и плюралистичности, причем соотношение между ними периодически меняется. Но и это состояние, похоже, преходяще. Уже появились симптомы формирования некоего метапространства, утверждение которого будет равнозначно исчезновению государства как основного субъекта принятия политических решений на конкретной территории.

Как ни парадоксально, но одним из факторов кризиса государства является повышение образованности и информированности людей, от которых становится все труднее скрыть несостоятельность последнего в выполнении своих функций. В результате усиливается отчуждение граждан от государства, углубляется недоверие к нему. Убеждение в безнадежной коррумпированности государства, в его неспособности руководить экономикой характерно, в частности, для стран Латинской Америки, население которых зачастую видит в политиках злейших врагов демократии.

Под сомнением оказалось положение о том, что государство представляет собой важнейший источник гражданской идентичности. Конечно, в ситуации относительного покоя вопрос об идентичности может показаться надуманным, но он резко заявляет о себе во времена актуализации выбора. В целом лояльное отношение к государству, его политике есть следствие обмена. Пока государство обеспечивает благополучие, безопасность, оно может рассчитывать на лояльность граждан. Особенность современной ситуации в том, что во многих регионах мира лояльность семье, корпорации, партии начинает играть большую роль, нежели лояльность государству.

Не ясны и пределы роста числа государств. К моменту образования ООН в мире было примерно 60 государств, в настоящее время их около 200. Более того, по некоторым оценкам, из 5000 народов планеты, лишенных государственности, почти 1000 имеют шанс ее приобрести. Понятно, что подобное увеличение резко усилит анархическое начало в мировом развитии. Но проблема гораздо шире. Времена, благоприятствующие государственному строительству, прошли. Уже нет территорий, население которых демонстрировало бы выраженное стремление к обретению собственной государственности и при этом было бы однородным в этническом, конфессиональном и социкультурном плане. Поэтому новые государства зачастую возникают там, где отсутствует необходимая для этого социокультурная среда. Не случайно большинство новообразованных государств проявляют полную неспособность выполнять те функции, ради которых они, собственно, и создавались. Принцип суверенитета начинает прикрывать власть бандитов, внутригосударственный беспредел. Отсюда - столь характерные для молодых государств перманентные мятежи и массовые нарушения общественного порядка.

Глобализация резко актуализировала проблему “четвертого мира”, которая начала обсуждаться еще в период распада колониальных империй и превращения бывших колоний в независимые государства. Именно тогда была сформулирована концепция, согласно которой ликвидация традиционной колониальной системы, а также предоставление народам автономии в рамках политэтнических государств есть не более чем первый шаг в решении национального вопроса в мире или даже фаза в бесконечном процессе обострения и ослабления межэтнических противоречий. По мнению сторонников данной концепции, многонациональные государства (а таковых, как известно, большинство) являются скрытыми империями, оккупировавшими территорию малых народов и навязывающими им порядок, который угоден лишь так наз. “титульной нации”. Для достижения этой цели используются как “невинные” механизмы аккультурации, так и прямой геноцид, этноцид, экоцид, насильственное выселение. Порочность такого положения обосновывается не только ссылками на недопустимость лишения народов права на самоопределение и свободное развитие, но и тем, что подавление и ассимиляция малых этносов наносят колоссальный вред природной среде. 
Сильная сторона рассматриваемой концепции, на мой взгляд, заключается в том, что она указывает на неприемлемость принудительной унификации народов. Подобная практика чревата разрушением самого государства. Поглощая огромные материальные и людские ресурсы, политика насильственного объединения лишь усиливает отчуждение и враждебность в межэтнических отношениях. Поэтому прибегающие к ней государства фактически готовят почву для своего будущего распада.

Вместе с тем мне представляется необоснованным тезис о том, что проблему “четвертого мира” можно решить путем ликвидации многонациональных государств и создания на их основе множества самостоятельных единиц. Более эффективным, как мне кажется, было бы формирование на территории крупных государств автономных демократических регионов - примерно масштабов Венеции, Ломбардии, Бургундии. Правда, и в этом случае остается открытым целый ряд серьезных вопросов, в частности, вопрос о том, хватит ли у такого рода образований ресурсов для решения задач, встающих в связи с глобализацией мира. Однако я уверен, что поиски решения должны идти именно в этом направлении.

Вероятно, наиболее важным признаком кризиса современного государства является утрата им четких позиций по поводу актуальных проблем международного и внутринационального развития. По сути дела, кризис обусловлен не столько остротой вызовов, с которыми сталкивается государство, сколько нарастающей неопределенностью его отношения к этим вызовам, неподготовленностью к ним мира в целом, в т.ч. гражданского общества развитых стран. Последнее тем более существенно, что именно культура Севера и породила современное государство.

С разработкой темы глобализации отчетливо обнаружилась неадекватность или, по меньшей мере, спорность некоторых центральных положений традиционной теории государства. Мифом, например, оказалось представление о том, что внуригосударственные отношения есть зона порядка и стабильности, а международные - сфера хаоса и неопределенности. Выяснилось также, что государства отнюдь не являются гомогенными акторами. Политика государств чаще всего непоследовательна, а сами они внутренне расколоты и испытывают влияние множества групп, в т.ч. криминализированных. Как справедливо отмечает И.Фергюсон, “все государственные политические стратегии, даже если они идентифицируемы, имеют негосударственные источники”.

Но несмотря на все это, я убежден, что серьезных оснований для заключения о том, будто государство себя изжило, подобно тому, как когда-то изжили себя традиционные империи, нет и вряд ли они появятся в обозримой перспективе. Нужно анализировать реальные проблемы, реальные кризисы, не торопясь объявлять их системными. Конечно, какие-то конкретные государства могут распасться, но жизнеспособность государства как универсального института власти весьма высока. Пока еще даже нельзя сказать, станет ли выстраиваемая в Европе новая политическая конструкция альтернативой национальному государству или же дополнением к нему. На данный момент на европейском континенте развиваются две параллельные тенденции: сверху складывается некое супергосударство, внизу идет формирование государств-регионов. Однако каких бы то ни было признаков отказа от института государства как такового не наблюдается.

Т.П.Лебедева. На мой взгляд, самым серьезным “вызовом” глобализации является кризис идентичности как коллективной, так и индивидуальной. Быстрая интернационализации всех сфер общественной жизни (экономической, социальной, политической, духовной) существенно меняет не только условия формирования идентичности, но и ее характер. Как пишет У.Бек, “вместе с глобализацией... рушится структура основных принципов, на которых до сих пор организовывались и жили общества и государства, представляя собой территориальные, отграниченные друг от друга единства... Образуются новые силовые и конкурентные соотношения, конфликты и пересечения между национально-государственными единствами и акторами, с одной стороны, и транснациональными акторами, идентичностями, социальными пространствами, ситуациями и процессами - с другой”. Расшатывая традиционную систему формирования личности, глобализация подготавливает почву для возрастания роли факторов, менее детерминированных национальной социокультурной средой. Но последствия этого процесса нередко бывают весьма болезненными, особенно в бедных странах, где трансформация традиционной системы, как правило, сопровождается социальной и культурной деградацией, маргинализацией, утратой ориентиров. А ведь от того, какими будут представления индивидов о себе и своем положении в обществе, какими будут их мотивы, ценности, нормы, жизненные смыслы, в конечном счете зависит будущее человечества. 
Как реагирует общество на эту ситуацию? Данный вопрос был детально исследован в книге М.Кастельса “Информационная эпоха: экономика, общество и культура”. Согласно заключению автора, глобализация вызывает к жизни два типа идентичности: идентичность сопротивления и идентичность проектную, ориентированную на адаптацию к новым реалиям. (Думается, что идентичность второго типа было бы точнее назвать защитно-проектной, ибо она предполагает не только использование обусловленных глобализацией возможностей развития, но и преодоление ее негативных последствий.) Поиск идентичности осуществляется путем самоорганизации. В настоящее время большинство общественных движений и ассоциаций строятся на идентичности сопротивления, и для них характерны протестные настроения, неприятие всех аспектов глобализации, минимальная включенность в традиционные гражданские структуры. Тем не менее, по убеждению Кастельса, некоторые из таких объединений способны в перспективе перейти к проектной идентичности, образовав глобальное гражданское общество.

Социальные движения, основанные на идентичности сопротивления, могут быть как конструктивными (когда они фокусируют свое внимание на действительно негативных аспектах глобализации), так и деструктивными. Принято считать, что наибольшим деструктивным потенциалом обладают сегодня религиозные и национальные движения, особенно в экономически отсталых странах. Активизация национального и религиозного сознания - вполне естественная реакция на разрушение связей с традиционной общностью, ослабление национального государства, дестабилизацию рынка труда, проникновение “чуждых” идей, ценностей и моделей поведения. В условиях, когда рушится привычный мир, объединение вокруг первичных источников идентичности помогает людям обрести почву под ногами. Беда, однако, в том, что находятся силы, стремящиеся использовать подобные настроения для утверждения и укрепления своей власти. Именно в этом я вижу истоки агрессивного национализма и религиозного фундаментализма, а также таких их порождений, как геноцид и терроризм.

Подобно Кастельсу, я убеждена, что религиозные и национальные движения отнюдь не обречены на идентичность сопротивления. Преодолеть ее можно путем проведения политики культурного синтеза: традиционные ценности будут помогать людям определять свое “я”, а новые - ориентироваться в сферах экономики, политики, образования, потребления и т.д. Это позволит личности, группе, обществу разрешить внутренний конфликт и включиться в новый мир, сохранив свою автономную идентичность (что совсем не противоречит глобализации, ибо глобализация, культурный плюрализм и дифференциация тесно связаны).

К числу деструктивных социальных движений часто относят и движение антиглобалистов, забывая о том, что значительную его часть составляют “умеренные” ассоциации (экологические, молодежные, феминистские, защиты прав потребителей, борьбы против расовой дискриминации и т.д.). К сожалению, в него входят и организации левых радикалов и анархистов, склонные к агрессивным, жестким методам протеста (именно их акции обычно получают освещение в СМИ и определяют отношение к движению в целом). Чтобы приобрести авторитет в цивилизованном мире, эффективно влиять на ход глобализации, требовать от международного бизнеса социальной ответственности, антиглобалистское движение (или движение за альтернативную глобализацию, как предпочитают называть себя многие его сторонники) должно выдвигать реальные, достижимые цели, быть готовым к компромиссам и, конечно, избавиться от экстремистского крыла.

Завершая свое выступление, я хотела бы вкратце затронуть проблему поиска идентичности российским обществом. Уверена, что нам пора отказаться от своей зацикленности на вопросе о том, кто мы и насколько отличаемся от других, и сосредоточить внимание на той социальной деятельности, которая позволит нам вписаться в глобальный мир и найти в нем свое место. Необходимо оставить в стороне пресловутые рассуждения об “особом пути” России, о навязывании российскому обществу чуждых ему западных ценностей. Прочное положение в глобальном мире стране может обеспечить только инновационный тип развития, а он, в свою очередь, требует человека свободного. В связи с этим считаю, что на сегодняшний день нашей важнейшей задачей является дальнейшая демократизация и целенаправленное культивирование либеральных ценностей.

Те трудности, с которыми столкнулась Россия в ходе демократического транзита, отнюдь не свидетельствуют об органической несовместимости ее национальной культуры с ценностями либеральной демократии. Российская культура, безусловно, гораздо ближе к западной, нежели культура Японии, Турции, Индии, Южной Кореи и ряда других стран, достигших немалых успехов на пути демократизации. В российской ментальности издавна присутствовал христианский постулат свободы воли, но он не был материализован в светском мире. Настало время, когда наше общество, опираясь на собственный опыт, 
позитивный и негативный, а также используя опыт западноевропейских стран, может найти механизмы обеспечения свободы и прав человека. Конечно, переход к демократии - сложный и длительный процесс. Но, обретая идентичность, основанную на универсальных либеральных ценностях, мы будем одновременно двигаться и к консолидации демократии.

Ю.С.Назарова. В предыдущих выступлениях речь шла преимущественно о наиболее общих свойствах и закономерностях глобализации. Я же хочу обратить внимание на технологические, операциональные факторы данного процесса. Я абсолютно уверена, что никакого “автоматического” воздействия финансовых рынков на ситуацию в политической сфере не существует. Без применения определенных технологий трансформировать политические процессы и отношения невозможно.

Конечно, речь отнюдь не идет о “целенаправленном” выстраивании глобального мира некой группой людей (или стран). Таких возможностей нет даже у лидирующих государств и структур. Тем не менее очевидно, что ресурсное обеспечение и/или статусное (властное) положение ряда акторов позволяет им сознательно задавать отдельные параметры мирового политического процесса. Одним из важнейших каналов их влияния являются СМИ.

Практика показывает, что через СМИ и другие информационные структуры осуществляется культурное, а следовательно - и политическое воздействие на “общественность”. Иными словами, не будучи прямыми носителями власти, СМИ выступают технологическими инструментами глобализации (разумеется, если кто-то их направляет). Политические стратегии акторов, стремящихся влиять на ход глобальных процессов в мировом или локальном масштабе (надгосударственных объединений, национальных государств, ТНК и т.п.), выражаются прежде всего в их информационных стратегиях.

В настоящее время “погоду” на мировом рынке информации делают такие “мэтры” информационного бизнеса, как Си-Эн-Эн, Рейтер, Франс пресс, Ассошиэйтед пресс и ряд других. Именно они определяют методы и механизмы коммуникации между политическими мирами, именно через них осуществляется позиционирование глобальных акторов. По отношению к ним, по-видимому, правомерно говорить не столько о зависимости от каких-то конкретных политических игроков, сколько о приверженности ценностям новой рациональной организации мирового информационного, экономического и политического пространства (т.е. той системе базовых принципов, которую де-факто и воплощает глобализация). Но уже сама эта установка дает возможность наиболее значимым центрам и организациям использовать их для продвижения свох инвестиционных и иных проектов и тем самым корректировать движение глобализационных потоков.

Доминирование мировых информационных игроков вовсе не означает, что национальные государства не должны пытаться реализовывать собственные информационные стратегии. Конечно, за счет одних технологий нельзя компенсировать дефицит экономических и других необходимых для вхождения в информационное общество ресурсов. Но они могут сгладить последствия отставания и открыть пути для максимально эффективной реализации имеющихся возможностей.

Информационно-политическая деятельность национальных государств имеет множество аспектов, однако мне представляется важным акцентировать то обстоятельство, что информационные структуры должны использоваться для повышения эффективности собственно управленческой деятельности. В последние годы Россия, безусловно, предприняла ряд шагов, способствующих интеграции внутреннего информационного пространства и новому позиционированию в нем центральных и региональных властных органов. Это проявилось, в частности, в совокупности акций, нацеленных на реформирование медиарынка, коммерциализацию деятельности СМИ и создание современной медиаиндустрии.

К сожалению, эти конструктивные шаги не сопровождались попытками наладить партнерский диалог власти с гражданским обществом. Более того, несмотря на повышение информационной открытости России, ее динамика в этом отношении существенно отстает не только от европейской, но и от мировой. Между тем в нынешних условиях страна, не обладающая четкими демократическими приоритетами в информационной сфере, не в состоянии продвинуться в мировом информационном пространстве, а значит - и обрести необходимое политическое влияние на процессы глобализации. Сегодня недостаточно, чтобы вектор трансформации информационного пространства был направлен в сторону рыночной модели взаимодействия государства, общества и СМИ. Для того чтобы закрепить отечественные структуры на мировом информационном рынке, необходимо более существенное продвижение. 
Поскольку нашим СМИ трудно отвоевать себе место на мировом информационном рынке, основной акцент должен быть сделан на информационные агентства. Именно эти технологические структуры могут реализовывать коммуникативный потенциал российского общества на международном уровне, способствовать его интеграции в мировые политические порядки.

Существуют две стратегии проникновения на зарубежные информационные рынки. Первая из них установление прямых контактов с конечными потребителями информации. Эта стратегия лежит в основе деятельности таких крупнейших российских агентств, как “Интерфакс”, РИА и ТАСС, имеющих немало подписчиков во многих странах мира. Вторую стратегию можно условно назвать опосредованным присутствием. В данном случае агентства используют не только собственные каналы распространения информации, но и иностранные дистрибьюторские системы, в т.ч. сети и терминалы зарубежных информационных структур.

Но чтобы достойно войти в глобальное информационное пространство, нужно откорректировать и качество предоставляемой информации, сделать ее понятной для зарубежной аудитории. В содержательном плане важно продемонстрировать людям линию российского государства на сохранение национальной идентичности и одновременно его приверженность политике демократизации и открытости. Только таким образом можно преодолеть или хотя бы снизить сохраняющееся в общественном мнения ряда ведущих стран мира недоверие к России.

И.А.Рысева. Я хотела бы продолжить обсуждение вопроса о роли информационных структур в становлении глобальных порядков и обратить внимание на тот факт, что в условиях транснационализации мирового развития СМИ не могут выполнять свои задачи прежними способами, в частности, без широкого использования сетевых возможностей. Традиционные электронные (радио, телевидение) и печатные СМИ вынуждены искать свою нишу в глобальной сети Интернет. В связи с этим можно говорить о постепенном превращении Интернета в основной источник информации для современного человека.

Сетевые СМИ - электронные газеты, журналы, специализированные новостные порталы, информационные агентства разного уровня и т.д. - позволяют преодолеть многие сложности, с которыми сталкиваются СМИ традиционные. Они не только обеспечивают свободу информации, но и сглаживают различия между крупными и мелкими медиа-субъектами. “Сетевое вещание” не требует больших финансовых затрат, а информационная емкость сетевых источников информации намного выше, чем у источников вне сети. В результате даже самые мелкие субъекты информационного рынка получают шанс донести свою продукцию до неограниченного числа пользователей. А это, в свою очередь, разрушает монополию крупных медиа-структур, поощряя конкуренцию в информационном пространстве.

Преимущества сетевых СМИ отчетливо проявляются на региональном и местном уровне. Сегодня люди часто бывают хорошо осведомлены о том, что происходит в мире, но не знают, что делается в их городе или районе. Такого рода информация обычно не попадает на ленты информационных агентств, а соответственно - в выпуски новостей и на страницы центральных газет. Между тем местные и региональные издания нередко испытывают финансовые трудности и находятся в зависимости от локальных политических и экономических элит, что негативно сказывается на качестве их информационной продукции. С развитием сетевого вещания эта проблема может быть решена.

Конечно, становление сетевого информационного пространства порождает немало собственных проблем. Одна из них - отсутствие механизмов контроля за соблюдением авторских прав при использовании информации. Кроме того, сетевые СМИ нередко игнорируют потенциальные социальные последствия распространяемой информации и потому могут спровоцировать дестабилизацию ситуации и рост напряженности в отдельных странах и регионах. Думаю, однако, что все это — болезнь роста, которая со временем будет преодолена.

А.И.Соловьев. Я думаю, у нас состоялся весьма интересный и полезный разговор. И хотя многие вопросы так и не получили ответа, мне кажется, что сегодня нам удалось прояснить не только наши позиции, но и многие аспекты самого феномена глобализации.

Политический облик постсовременности выстраивается буквально на наших глазах. Сегодня уже очевидно, что логика, заложенная предшествующим историческим развитием — от “государства-полиса” через “национальное государство” к “континентальному” - уже не срабатывает. Многие институциональные 


\section{Глобализация}

структуры мировой политики утрачивают гибкость, международные организации теряют в “весе”, а формирующиеся сетевые сообщества (в т.ч. региональные) не в состоянии преодолеть нарастание хаоса. В ситуации столь стремительных качественных трансформаций ни одно государство мира уже не может быть уверено в устойчивости своего места в мире. (Те же США, если они растратят в иракском или каком-то ином проекте слишком много ресурсов, могут быстро уступить роль мирового лидера единой Европе). По-видимому, именно этой насыщенной динамикой и объясняется сложность описания происходящих в последние годы процессов.

Несомненно, что глобализация меняет и самого человека. Рационализация, как известно, всегда “ужимала” высокие идеи. Но я не сомневаюсь в том, что, утрачивая ряд традиционных гуманистических ценностей, современные люди одновременно обретают многие другие, не менее значимые для их дальнейшего существования. В России, кстати, тоже идет поиск новых смыслов жизни, ориентиров развития. Другой вопрос: будут ли они лучше старых?

Очень важно, что в ходе нашей дискуссии был затронут и технологический аспект глобализации. Ведь от приемов управления объективными процессами (например, транснационализацией финансовых рынков или формированием новых центров власти) во многом зависят и их последствия — локальные и глобальные.

В любом случае я уверен, что рефлексия по поводу этих острейших проблем современного мира окажется небесполезной и для дальнейшего осмысления феномена глобализации, и для сферы практической политики. 